\title{
Pengaruh Pemenuhan Slot Time Terhadap Target Take-Off Time di Perum LPPNPI Cabang Utama Jakarta Air Traffic Service Center
}

\author{
Daniel Dewantoro R. ${ }^{1, *}$, Zonar Anjab Rabbani ${ }^{1}$, Hadi Prayitno ${ }^{2}$ \\ ${ }^{1}$ Politeknik Penerbangan Indonesia, Tangerang. \\ ${ }^{2}$ Politeknik Penerbangan Medan, Jln. Sempakata No. 85 Medan \\ *daniel.dewantoro@ppicurug.ac.id
}

\begin{abstract}
This research was conducted at the Jakarta Air Traffic Service Center (JATSC) starting from March 2020 to July 2020 using the quantitative associative correlation method. The research population was all departing aircraft at Soekarno-Hatta International Airport using various runways and taxiways and aprons. The samples used were all aircraft departing from Soekarno-Hatta International Airport and navigation services were provided by the Jakarta Air Traffic Service Center (JATSC) in three, namely from November 2019 to January 2020 and using cluster (area) sampling techniques. The data collection technique used is a documentation study containing data on the fulfillment of Target Take Off Time (TTOT) and data on each aircraft movement required for research (such as aircraft identification, Estimate Off Block Time, taxitime, etc.). Furthermore, the data analysis technique use disparametric statistics in the form of data assumption tests followed by relationship analysis tests.
\end{abstract}

Keyword: ATFM, delay, slot time, Target Take Off Time

\section{PENDAHULUAN}

Peningkatan traffic khususnya dalam bidang penerbangan terus terjadi seiring perkembangan waktu, maka dari itu diperlukan strategi yang mumpuni untuk melaksanakan pengaturan arus lalu lintas traffic. Dalam hal ini AirNav Indonesia telah memberlakukan sistem pengaturan arus lalu lintas udara berdasarkan rekomendasi dari International Civil Aviation Organitaion (ICAO) yang disebut dengan Air Traffic Management Sistem (ATFM) serta dipadukan dengan regulasi nasional. Berkaitan dengan hal tersebut, sistem pengaturan yang telah dilakukan di Indonesia adalah sistem SlotTime.

Slot time adalah alokasi ketersediaan waktu terbang yang mana slot time menjadi suatu acuanmaskapai penerbangan dapat mengudara dan mendarat di suatu bandara. Slot time merupakan salah satu sarana dalam melaksanakan konsep strategic air traffic flow management dimana dengan slot time ini dapat memetakan dan meratakan jadwal penerbangan yang terlalu padat pada waktu tertentu. Jadwal penerbangan pada waktu/jam yang padat dapat dialokasikan pada waktu/jam yang renggang pergerakannya sehingga dapat memaksimalkan arus penerbangan di Indonesia ini. Selain itu, slot time juga dapat membantu mengurangi tingkat penundaan atau delay suatu maskapai penerbangan.

Sistem pengaturan tersebut telah berlaku pada 35 bandara di Indonesia sejak 2015 yang mana salah satunya diterapkan pada Bandara Internasional SoekarnoHatta yang mana bertujuan untuk mengurai kepadatan traffic pada bandara tersebut. Tetapi dalam penerapan dilapangan belum maksimal, hal ini dapat dilihat dari 
tingkat On Time Performance (OTP) di Bandara Internasional Soekarno-Hatta menurut lembaga survey oleh Official Air Guide (OAG) suatu perusahaan analisis penerbangan di Inggris menunjukan OTP Bandara Internasional Soekarno - Hatta pada bulan November 2018 menunjukan angka sebesar 65,9\% dari total traffic-nya, angka tersebut masih tergolong rendah. Angka OTP tersebut dapat disimpulkan bahwa terjadi penundaan atau delay sebesar $34,1 \%$ yang terjadi di Bandara Internasional Soekarno - Hatta (Town,2018).

Dari pernyataan diatas dapat dikesimpulkan bahwa masih terjadinya kepadatan yang belum terurai di Bandara Internasional Soekarno-Hatta. Kepadatan ini disebabkan oleh beberapa faktor. Ditinjau dari segi penetapan slot time, di Indonesia hanya menggunakan faktor Estimate Off Block Time (EOBT) yang mana menjadi acuan untuk pesawat melakukan push back. Hal ini tidak memperhitungkan komponen penghitungan lain yaitu Variable Taxi Time (VTT) untuk menentukan Target Take-Off Time (TTOT) sehingga seringkali ditemukan ketika sebuah pesawat telah memenuhi slot timeyang diberikan (on slot) tetapi mengalami hambatan akibat kepadatan yangterjadi pada taxiway untuk menunggu giliran penggunaan runway pada saat ingin melakukan proses departure sehingga menyebabkan delay yang berdampak pada traffic departure pada jam berikutnya.

\section{METODE PENELITIAN}

Metode yang digunakan dalam penelitian ini adalah metode kuantitatif asosisatif korelasi. metode ini diperuntukan untuk mendapatkan besaran pengaruh hubungan antar slot time dengan Target Take Off Time (TTOT) yang mana besaran hubungan dan pembuktian asumsi awal di uji dengan beberapa uji asumsi dasar.

\subsection{Metode Pengumpulan Data}

Pengumpulan data pada penelitian ini menggunakan teknik studi dokumentasi. Studi dokumentasi adalah merupakan teknik pengumpulan data yang tidak langsung ditujukan kepada subyek penelitian. Dokumen yang diteliti bermacam-macam, tidak harus dokumen resmi tetapi bisa berupa buku harian, surat pribadi, laporan, notulen rapat, catatan kasus dan lain- lain (Pradana, 2019).

Adapun dokumen yang diteliti pada penelitian kali ini adalah dokumen yang berisikan data pemenuhan slot time penerbangan keberangkatan, dan Target Take Off Time (TTOT) Penulis menggunakan metode ini dikarenakan sudah adanya laporan tertulis mengenai, data slot time penerbangan keberangkatan, data pemenuhan Target Take Off Time (TTOT) dan data setiap pergerakan pesawat yang dibutuhkan untuk penelitian (seperti aircraft identification (ACID), Estimate Off Block Time (EOBT), taxi time, standard taxi duration, airbone time, dll) pada bulan November 2019 sampai dengan Januari 2020.

Pada penelitian ini penulis menggunakan pengelompokan data sesuai dengan izin rute yang tertera di Peraturan Menteri Perhubungan Nomor PM 38 tahun 2017 Pasal 32 ayat 2 yang mana dikelompokan berdasarkan dengan Hari Operasi (HO) yang terdiri dari jumlah penerbangan keberangkatan satu hari dalam satu bulan. 
Tabel 1. Pengelompokan jumlah penerbangan keberangkatan sesuai hari operasi.

\begin{tabular}{cllll}
\hline & & \multicolumn{3}{c}{ Bulan } \\
\cline { 3 - 5 } No & Hari & Nov & Des & Jan \\
\hline 1. & Senin & HO1 & HO8 & HO15 \\
\hline 2. & Selasa & HO2 & HO9 & HO16 \\
\hline 3. & Rabu & HO3 & HO10 & HO17 \\
\hline 4. & Kamis & HO4 & HO11 & HO18 \\
\hline 5. & Jumat & HO5 & HO12 & HO19 \\
\hline 6. & Sabtu & HO6 & HO13 & HO20 \\
\hline 7. & Minggu & HO7 & HO14 & HO21 \\
\hline
\end{tabular}

Penulis menggunakan data keberangkatan penerbangan yang diperoleh dari AirNav Indonesia Cabang Utama Jakarta Air Traffic Service Center (JATSC) lebih tepatnya pada unit Air Traffic Flow Management (ATFM). Data penerbangan keberangkatan tersebut diantaranya berasal dari pelaporan daily movement yang diisi oleh personel ATC pada unit TWR, yang mana pada unit tersebut didapatkan seluruh waktu pergerakan pesawat yang akan melakukan proses keberangkatan, dimulai dari EOBT yang direalisasikan dengan slot time, start up time, push back time, taxi time, hingga last contact time atau transfer time ke unit selanjutnya.

\subsection{Metode Analisis Data}

Setelah data slot time dan Target Take Off Time (TTOT) telah terkelompokkan berdasarkan hari operasi maka analisis data dilakukan melalui beberapa uji, yaitu berupa :

a. Uji normalitas data

b. Uji linieritas data

c. Koefisien korelasi

d. Koefisien determinasi

e. Regresi linier sederhana

f. Uji hipotesis t (parsial)

\section{HASIL DAN PEMBAHASAN}

Perhitungan berdasarkan dengan pengelompokan data pada tabel 2 merupakan hasil dari pengolahan dan perhitungan yang dilakukan peneliti yang dibantu dengan aplikasi SPSS versi 25 Dimana hasil analilis hubungan pengaruh antara slot time dengan Target Take Off Time (TTOT) memiliki hubungan yang kuat.

Tabel 2. Perhitungan Pemenuhan Slot Time (X) dan Pencapaian TTOT (Y)

\begin{tabular}{|c|c|c|c|c|c|c|}
\hline No. & HO & $\begin{array}{c}\text { Total } \\
\text { Penerbangan } \\
\text { Keberangkatan }\end{array}$ & $\begin{array}{c}\text { Total } \\
\text { Pemenuhan } \\
\text { Slot Time } \\
(\mathrm{X})\end{array}$ & $\begin{array}{c}\text { Persentase } \\
\text { Pemenuhan } \\
\text { Slot Time }\end{array}$ & $\begin{array}{c}\text { Total } \\
\text { Pencapaian } \\
\text { TTOT (Y) }\end{array}$ & $\begin{array}{c}\text { Presentase } \\
\text { Pencapaian } \\
\text { TTOT }\end{array}$ \\
\hline 1 & $\begin{array}{c}\text { HO } \\
1\end{array}$ & 2081 & 1925 & $93 \%$ & 1300 & $62 \%$ \\
\hline 2 & $\begin{array}{c}\text { HO } \\
2\end{array}$ & 2147 & 1983 & $92 \%$ & 1366 & $64 \%$ \\
\hline
\end{tabular}




\begin{tabular}{|c|c|c|c|c|c|c|}
\hline 3 & $\begin{array}{c}\mathrm{HO} \\
3\end{array}$ & 2160 & 1968 & $91 \%$ & 1328 & $61 \%$ \\
\hline 4 & $\begin{array}{c}\mathrm{HO} \\
4\end{array}$ & 2187 & 1966 & $90 \%$ & 1307 & $60 \%$ \\
\hline 5 & $\begin{array}{c}\mathrm{HO} \\
5\end{array}$ & 2867 & 2615 & $91 \%$ & 1612 & $56 \%$ \\
\hline 6 & $\begin{array}{c}\mathrm{HO} \\
6\end{array}$ & 2601 & 2429 & $93 \%$ & 1691 & $65 \%$ \\
\hline 7 & $\begin{array}{c}\mathrm{HO} \\
7\end{array}$ & 2263 & 2026 & $90 \%$ & 1347 & $60 \%$ \\
\hline 8 & $\begin{array}{c}\mathrm{HO} \\
8\end{array}$ & 2537 & 2397 & $94 \%$ & 1685 & $66 \%$ \\
\hline 9 & $\begin{array}{c}\mathrm{HO} \\
9\end{array}$ & 2909 & 2414 & $83 \%$ & 1483 & $51 \%$ \\
\hline 10 & $\begin{array}{c}\mathrm{HO} \\
10\end{array}$ & 2273 & 2041 & $90 \%$ & 1281 & $56 \%$ \\
\hline
\end{tabular}

a. Uji normalitas data

Uji ini menggunakan metode uji normalitas Kolmogorov- Smirnov dan mendapatkan hasil pada unstandarized residual adalah 0.067. Berdasarkan pengambilan keputusan (Syofian, 2017), data didapatkan dengan hasil yang normal. Berikut diagram grafik normalitas yang dibuat dengan menggunakan aplikasi Ms. Excel 2010 :

\section{Normal Probability Plot}

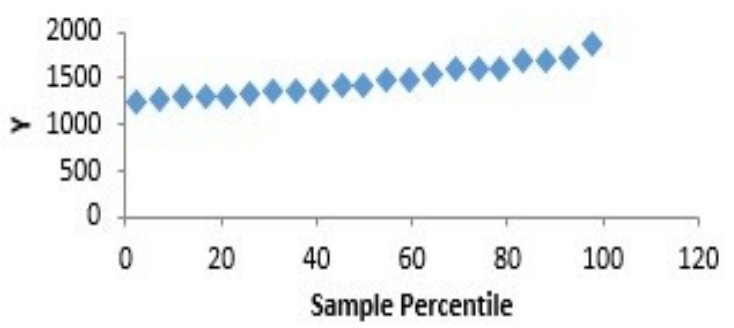

Gambar 1. Grafik normal probability plot

b. Uji linieritas data

Dari hasil output uji linieritas menggunakan program SPSS versi 25, uji linieritas data pada penelitian ini didapatkan nilai deviation form linierity sebesar 0.086. Berdasarkan pengambilan keputusan (Syofian, 2017), maka di dapatkan hasil terdapatnya hubungan yang linier antara variabel $\mathrm{x}$ dan variabel y.

c. Koefisien korelasi

Dari hasil output uji koefisien korelasi yang dilakukan dengan aplikasi SPSS versi 25 dengan Pearson Corelation yang mana mendapatkan hasil 0.756. Berdasarkan pengambilan keputusan (Syofian, 2017), tingkat korelasi pada penelitian ini memiliki nilai tingkat hubungan kuat antar variabelnya.

d. Koefisien determinasi

Koefisien determinasi ditentukan dengan persamaan sebagai berikut:

$$
\mathrm{KD}=(\mathrm{r}) 2 \times 100 \%
$$

Berdasarkan persamaan diatas, didapatkan koefisien determinasi 57\% 
dengan nilai $\mathrm{r}=0.756$ sehingga dapat di tarik kesimpulan bahwa pengaruh antar variabel sebesar $57 \%$ dan $48 \%$ yaitu sisa dari perhitungan tersebut dipengaruhi oleh faktor lain.

e. Regresi linier sederhana berikut:

Regresi linier sederhana ditentukan dengan persamaan sebagai $\mathrm{Y}=\mathrm{a}+\mathrm{bX}$

Dari hasil output SPSS versi 25 persamaan regresi yang diambil dari unstandardized beta cooficients, yaitu $\mathrm{a}=366,91 \mathrm{dan} \mathrm{b}=0,505$. Sehingga persamaan regrsi yang digunakan pada penelitian ini adalah:

$$
\mathrm{Y}=366,913+0,505 \mathrm{X}
$$

Hal tersebut dapat diartikan bahwa setiap penambahan 1 poin tingkat pemenuhan slot time (X), maka Target Take Off Time (TTOT) (Y) akan bertambah sebesar 0,505 ada konstanta 366,913.

f. Uji hipotesis t(parsial)

Dari hasil output SPSS versi 25 diketahui nilai thitung $=5,037$. Untuk mencari nilai ttabel menggunakan persamaan rumus sebagai berikut :

$$
\begin{aligned}
\text { ttabel } & =\mathrm{n}-\mathrm{k}-1: \alpha / 2 \\
& =21-1-1: 0,05 / 2 \\
& =19: 0.025
\end{aligned}
$$

Maka diketahui tabel $=2,09302$ sehingga dapat dipadukan dengan hasil output perhitungan SPSS : thitung $=5,037>2,09302$ (ttabel) dan dapat disimpulkan bahwa terdapat pengaruh pemenuhan slot time terhadap Target Take Off Time (TTOT) yang merupakan pernyataan dari Ha.

\section{KESIMPULAN}

a. Dari data yang penulis ambil dengan jumlah total 49.096 pesawat yang melakukan keberangkatan dari bandara tersebut dengan 46.053 atau 94\% jumlah total pesawat yang memenuhi slot time mereka hanya terdapat 30.952 atau $63 \%$ jumlah total pesawat yang dapat memenuhi Target Take Off Time (TTOT) di Bandara Internasional Soekarno- Hatta.

b. Dari data yang penulis ambil, terdapat 15.101 atau $31 \%$ pesawat daritotalkeseluruhanpesawatyang memenuhi slot time tetapi tidak dapat memenuhi Target Take Off Time (TTOT). Hal tersebut dibuktikan bahwa belum terjadinya pengaturan penggunaan runway sehingga terjadi kepadatan pada taxiway untuk mengantri menunggu giliran untuk takeoff.

c. Dapat dibuktikan bahwa terdapat pengaruh pemenuhan slot time terhadap Target Take Off Time (TTOT) di Perum LPPNPI Cabang Utama Jakarta Air Traffic Service Center (JATSC). Pengaruh tersebut didasari dari persamaan regresi $\mathrm{Y}=366,913+0,505 \mathrm{X}$ dengan kekuatan pengaruh pemenuhan slot time dengan Target Take Off Time (TTOT) searah atau berbanding lurus. Kekuatan hubungan antara pemenuhan slot time terhadap Target Take Off Time (TTOT) memiliki tingkat hubungan yang kuat oleh koefisien korelasi sebesar 0,756. Kontribusi yang diberikan pemenuhan slot time terhadap Target Take Off Time (TTOT) sebesar 57\%. 


\section{DAFTAR PUSTAKA}

ICAO. (1984). Air Traffic Services Planning Manual. In www.icao.int. International Civil Aviation Organization. https:/www.icao.int/airnavigation/Lists/ T Documents/DispForm.aspx?ID=51

ICAO. (2016a). Annex 11 Air Traffic Services (Issue July). http://eurlex.europa.eu/resource.html?uri=cellar:8d56d9fd-339d-11e6-969e

01aa75ed71a1.0001.02/DOC 13\&format=PDF

ICAO. (2016b). Doc 4444 Air Traffic Management (Vol. 4444, Issue November). http://flightservicebureau.org/wp-content/uploads/2017/03/ICAO-Doc4444-Pans-

Atm-16thEdition-2016-OPSGROUP.pdf

ICAO. (2018). Doc 9971 Manual on Collaborative Air Traffic Flow Management (ATFM) (Third). International Civil Aviation Organization International Civil Aviation Organization. (2016). Long-Term Traffic Forecasts. July.

https://www.icao.int/Meetings/aviationdataseminar/Documents/ICAO-Long-Term-

Traffic-Forecasts-July-2016.pdf

Pradana, A. B. (2019). Metode Penelitian Ilmiah (3rd ed.). Sekolah Tinggi Penerbangan Indonesia.

Rumani,D.D., \& Tiarto, (2020), Enhance Airlines Deregulation Technique Commercial Air Transport Schedule Indonesia. 11(7),266-273.

Sugiyono. (2018). Metode Penelitian Kuantitatif. Alfabeta Bandung.

Syofian, S. (2017). Statistik Parametrik Untuk Penelitian Kuantitatif. Bumi Aksara. 